\title{
Modernization of Topographic Mapping by Japan Meiji Government - Introduction of French Army Mapping Technology and afterwards -
}

\author{
Shosuke Hosoi \\ Cartographic information office, Japan
}

\begin{abstract}
:
In Japan, the political system was changed greatly and new Meiji government under Meiji Emperor was born in 1868. Meiji government made great efforts to modernize Japan to hold its independence, hiring many professionals from the western advanced countries, sending many students to the western advanced countries, establishing obligatory education system, and so on.
\end{abstract}

It invited French military mission to modernize its army. The mission arrived in Japan in 1872 and stayed until 1880 changing its members. It included engineer officers as follows: Engineer captain Albert Jourdan (1872-1878),Engineer captain Ernest Vieillard (1873-1876), Engineer lieutenant captain Lucian Kreitmann (1876-1888) and two other engineer officers succeed until 1880. They worked fundamentally as the teachers of engineering including survey and mapping. Jourdan had additional works as Coast Defense plan and military construction such as Military School.

Jourdan participated in the Japan Coast Defense Planning Mission headed by French mission chief and ordered by the Army Minister,Yamagata. Coast Defense Plan maps were drawn for Kagosima Bay, Hakodate Bay, Tsuruga Bay, etc. Japanese officers of the General Staff Bureau engaged in making base maps for planning and supported the Mission in the field. The mapping technology would be transferred to the Japanese officers on the job.

The French Mission members began various military educations in 1872. TIZU SAISIKI (Map Color Rule) was published in 1873, which was translated book by Tomohiro Kosuge (later, the founder and the first director of Japan Land Survey) and others from a French map book brought by Jourdan. Jourdan and Vieillard taught military engineering, based on the textbooks 1855 for French engineer regimental schools, which were translated by T. Kosuge and others and published as KOUHEI SOUTEN (Manual for Military Engineers ) including Survey Division in 18731875.

In 1875, Grand Military Field Exercise was held in Narashinohara near Tokyo, when the field was surveyed at $1 /$ 10,000 scale with six plane table teams including T. Kosuge directed by E. Vieillard and a map was compiled and published next year.

In 1876, the first three textbooks on mapping of the Military School were printed ; SOKUTI KOUHON ( Land Survey Textbook), TIRIZUGAKU KOUHON ( Topography Textbook ) and SOKUTI KANHOU ( Rapid Survey Method in the Military School. The former two were Kreitmann's lecture records and the last one was translated book of a textbook of French Artillery and Engineering Application School Military Field Exercise was held in Narashinohara, when the field was surveyed with plane table method at 1/20,000 scale by the Military School pupils directed by L.Kreitmann. The compiled map was printed next year in the Military School.

In 1877, Seinan Civil War occurred in Kyushu Islan. Rapid survey maps were drawn by the members of the Survey Division of the Army Ministry. After the war, military field exercise was held in Shimoshidzu, when the field was surveyed with plane table method at 1/20,000 scale by the Military School pupils directed by L. Kreitmann. The compiled map was printed next year in the Military School.

In 1879, T. Kosuge was nominated to the head of the Survey Division, General Staff Office. He presented his second opinion, "Rapid Survey Plan of the Whole County "without triangulation which remained as the object of study to the head of the General Staff Office and this plan was accepted .

In 1880 following the "Rapid Survey Plan ", the rapid survey began with plane table method at 1/20,000 scale in Kanto metropolitan area on a large scale.

In 1881, according the comparison of the results of the normal triangulation and the graphical triangulation on the plane table, it was concluded that the former should be adopted for the whole country control point survey and that the survey system and organization should be changed..

In 1889, Army Land Survey was founded by T. Kosuge following the model of Prussian Land Survey, Germany and the first director was T.Kosuge. However, KOUHEI SOUTEN (Manual for Military Engineers ) Second Edition, Survey Division was published, translated from the textbook 1883 for the French Engineer Regimental School. 